\title{
Concept and application of implant connection systems: Part I. Placement and restoration of internal conical connection implant
}

\author{
Kyung-Ho Ko, Hyeon-Goo Kang, Yoon-Hyuk Huh, Chan-Jin Park, Lee-Ra Cho* \\ Department of Prosthodontics and Research Institute of Oral Science, College of Dentistry, Gangneung-Wonju National University, \\ Gangneung, Republic of Korea
}

The typical biomechanical properties of an internal conical connection (ICC) are axial displacement and loss of preload. The axial displacement of an ICC without a vertical stop can cause the loss of preload and a lowered occlusion. The stress of an ICC is concentrated on the contact interface of the abutment and not on the screw, and during placement, it is important to choose a wider coronal wall thickness as much as possible. The ICC should also be placed below the level of the bone crest. During the restoration of an ICC, care should be taken to ensure an appropriate abutment shape and an accurate connection. To get the best clinical results, it is important to select its wall thickness and place it in the appropriate position to restore it adequately. (J Dent Rehabil Appl Sci 2020;36(4):211-21)

Key words: internal conical connection; axial displacement; preload; restoration; placement

\section{서론}

임상적으로 만족스러운 결과를 보이는 대표적인 3가 지 임플란트와 지대주의 연결방식이 있다. 이는 1) 안착 형 외부 연결방식(slip fit external connection, EXT), 2) 원추형 내부 연결방식(internal conical connection, ICC) 및 3) 안착형 내부 연결방식(slip fit internal butt connection 또는 tissue level, TL)이다(Fig. 1). ${ }^{1}$ 가장 오 랫동안 사용되어온 EXT는 가장 긴 임상결과와 안정된 치료결과를 보여왔다. 하지만 연결부의 구조상 측방력이 나사(screw)에 집중되어 유발되는 보철적 합병증은 피할 수 없다.

그에 비해 내부 연결방식을 가진 두 가지 연결방식은 여러 생역학적 장점을 가진다. ICC는 모스 테이퍼(morse taper), 경사형 마찰 접촉(tapered friction fit), 원추형의

*Correspondence to: Lee-Ra Cho

Professor, Department of Prosthodontics and Research Institute of Oral Science, College of Dentistry, Gangneung-Wonju National University, 7 Jukheon-gil,

Gangneung-si, Gangwon-Do, 25457, Republic of Korea

Tel: +82-33-640-3153, Fax: +82-33-640-3103 , E-mail: lila@gwnu.ac.kr

Received: September 17, 2020/Last Revision: October 12, 2020/Accepted:

November 20, 2020
폐쇄성 연결(conical sealing) 등 여러 방식으로 명명되는 데, 기계적으로 우수하고 안정되며 스스로 고정시키는 접촉이라고 한다 ${ }^{2,3}$ ICC는 굽힘력에 대한 저항이 우수하 며, 응력분산이 유리하여 임플란트 주변골의 소실 위험 을 낮추었다. ${ }^{3-5}$ 임플란트와 지대주의 직경이 동일한EXT 에 비해 ICC는 임플란트 직경이 지대주에 비해 넓은 플 랫폼 스위칭(platform switching) 특성을 가지기 때문에 주변골 보존에 유리하며 TL은 골주변에 임플란트-지대 주 연결부위의 미세공극(microgap)이 없어 주변골 보존 에 유리하다. Weng 등 6 은 ICC는 수평적 골두께를 EXT 보다 더 넓게 확보할 수 있어 단단한 연조직의 봉쇄와 주 변골 유지에 장점이 있다고 하였다. ICC와 TL은 비록 약 간의 구조적 차이가 있으나 측방력 저항 및 연결의 안정 성, 나사의 파절이나 풀림 등의 생역학적인 면에서는 임 상적으로는 유의할 만한 차이가 없으므로 ICC의 생역학

Copyright@ 2020 The Korean Academy of Stomatognathic Function and Occlusion. (c) It is identical to Creative Commons Non-Commercial License. 

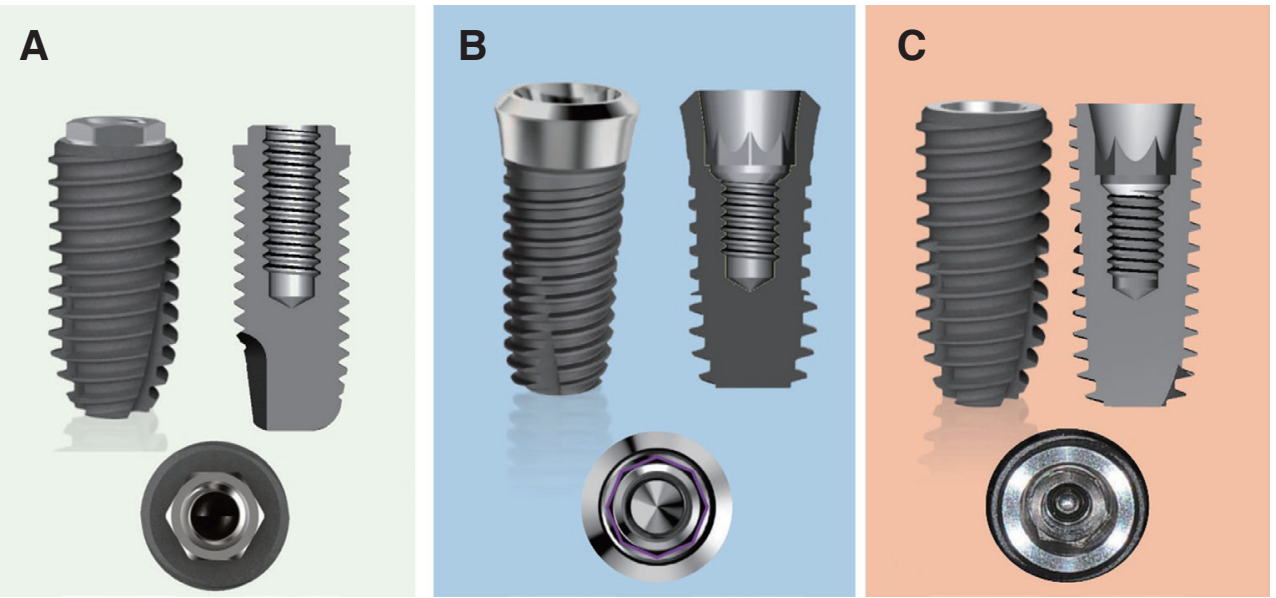

Fig. 1. Three types of implant-abutment connection. (A) External butt joint connection (EXT), (B) Slip fit internal butt connection, tissue level (TL), (C) Internal conical connection (ICC).

적인 특성을 먼저 이해하는 것이 필요하다.

\section{원추형 내부연결 임플란트의 생역학적 특성}

\section{수직변위 (axial displacement)}

임플란트-지대주 연결 간의 수직변위는 기계적 공차, 정착효과(settling effect), 쐐기효과의 3가지 요소 때문에 발생한다. ${ }^{8,9}$ 기계적 공차는 가공 시 치수의 편차 및 표면 거칠기에 의해 존재하는 임플란트 구성요소 간의 고유한 특성이다. 이러한 공차로 인해 모든 가공되는 조립 구성 품들은 정확한 크기와는 차이를 보인다. 제조업체에서는 임플란트 부품의 공차를 약 $5 \mu \mathrm{m}$ 정도라고 하고 있으나 연구결과에 따르면 EXT에서는 약 $50 \mu \mathrm{m}$ 미만이며, ICC 에서는 약 $90 \mu \mathrm{m}$ 미만 정도라고 한다. ${ }^{10}$ 여러 부위에 존 재하는 기계적 공차는 임플란트 보철물의 수직적 변위를 유발하는 한 요인이 된다.

정착효과(settling effect)는 거친 표면 사이에서 일어나 는 현상이다. ${ }^{11}$ 거친 부위는 반복하중이 가해지면 편평해 지면서 마모되어 가까이 근접하게 된다. 정착효과는 임 플란트-지대주 사이의 접촉면적이 더 큰 ICC가 EXT보다 더 많이 발생할 수는 있으나 그 양의 차이는 크지 않다. 기 계적 공차와 정착효과는 임플란트-지대주 연결방식에 관 계없이 금속가공과 관련하여 발생하는 요소이다. ${ }^{12}$

하지만 쐐기효과의 경우 EXT 임플란트에서는 없으며, ICC 중 수직적인 정지점이 없는 연결구조에서 수직하중 을 따라 지대주가 임플란트에 삽입되는 방향으로 변위
를 유발하는 것으로 접촉부위의 압력과 마찰저항을 증가 시키게 된다. ${ }^{13,14}$ 쐐기효과는 임플란트와 지대주의 표면 이 긴밀하게 접촉하도록 해준다. 조임력을 가한 상태의 임플란트와 지대주 간 연결단면을 조사해본 결과 티타늄 또는 지르코니아 지대주는 $1 \mu \mathrm{m}$ 미만의 긴밀한 접촉을 보였다. ${ }^{15}$ 임플란트-지대주 간 긴밀한 접촉은 마찰저항을 증가시키고 지대주의 유지력을 증가시키는 효과를 나타 낼 수 있다. ${ }^{15}$ 따라서 임플란트-지대주 간 연결의 미세간 극을 줄이기 위해서는 구강내 기능 후 전하중을 부여하 는 것이 좋다.

수직변위가 임플란트-지대주의 접촉을 증가시키는 긍 정적인 효과가 있는 반면 이를 초과하는 수직변위는 장 기적으로 문제를 유발할 수 있다. Lee 등 ${ }^{8}$ 은 조임력으로 약 $25 \mu \mathrm{m}$ 의 수직적 하중이 발생한 후에도 기능적 저작 력을 반복적으로 가했을 때 추가적으로 수직변위가 발생 했으며, 이는 최초의 3 회에서 가장 큰 변화를 유발한다 고 하였다. 이러한 결과는 최대 교합력 2 - 3회 이내에 금 속의 탄성한계 내에서 긴밀한 접촉이 발생하고, 이후 반 복되는 하중에는 점진적으로 안정화될 것으로 예측할 수 있으며, 이러한 자가억제의 메카니즘은 정형외과에서 사 용하는 티타늄 인공 관절에서도 유사하게 적용되고 있 다. ${ }^{16} \mathrm{Cho}$ 등 ${ }^{17}$ 은 임플란트 지대주의 반복하중 상황에서 수직변위와 함께 나사의 인장력 소실을 통한 전하중 소 실과 나사풀림을 보고하였다. 따라서 수직적 정지점이 없는 지대주를 환자의 구강내에 사용할 경우 수직적 변 위의 보상 및 전하중의 회복을 위한 추가적인 노력이 필 요하다는 것을 의미한다. 
수직변위는 또한 교합이 낮아지는 상황을 유발할 수 있다(Fig. 2). 임플란트 수복물의 교합이 저위교합이어야 한다는 것이 임플란트 시술 초기의 권장사항이었지만, 임플란트의 예후가 어느 정도 보장되었다고 평가되면서 자연치와 비슷한 교합접촉을 가지도록 하는 것이 권장된 다. ${ }^{18}$ 하지만 ICC에서 발생하는 수직변위에 의해 저위교 합이 발생하면 임플란트의 주위 치아는 과도한 교합력을 부담하게 되어 장기적으로 조기접촉 상황에 처하게 된 다. 이로 인한 골소실은 순환적으로 임플란트의 예후를 위협하는 원인이 될 수 있으므로 임플란트 최종보철물에 서 저위교합이 발생하지 않도록 조절하는 추가적인 노력 이 필요하다.

\section{나사 연결의 안정성}

초기 EXT임플란트 보철의 나사풀림은 심각한 문제 였다. 연결부의 안정성을 나사에 의존하는 EXT와는 달 리 ICC의 경우 임플란트-지대주의 접촉 안정성이 우수 하여 나사풀림이 낮을 것으로 예상되었다. 체계적 문헌 고찰에 따르면 나사풀림이 발생하지 않는 비율이 $97.6 \%$ 에 달하여 이 가정을 충족하는 것으로 보이지만 EXT도 $97.3 \%$ 여서 예상과는 달리 임플란트의 연결부에 따른 나 사풀림의 차이는 크지 않은 것으로 보인다. ${ }^{19}$ 오히려 ICC

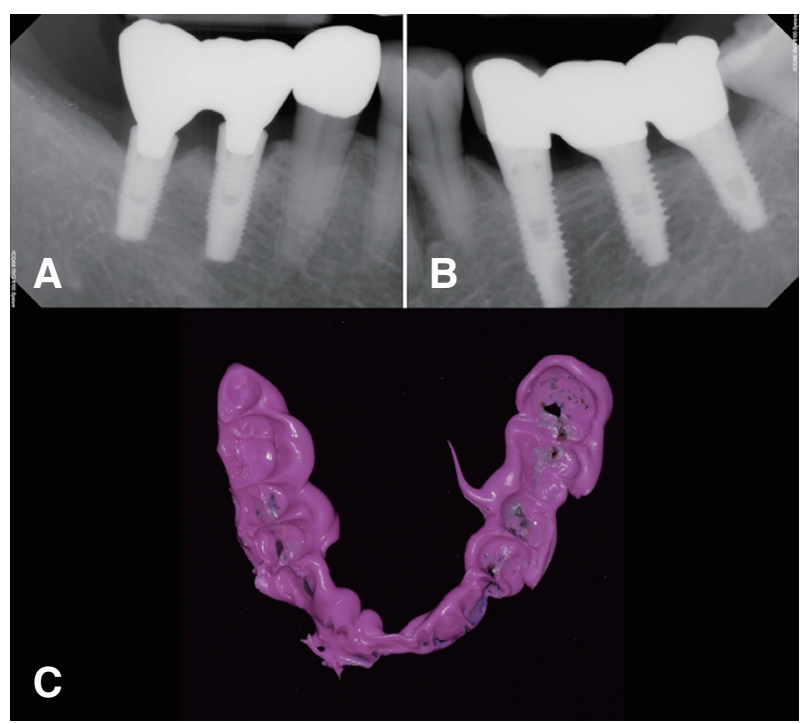

Fig. 2. Lowered occlusion induced by axial displacement. (A) Right molar implant prosthesis using internal conical connection implant, (B) Left molar implant prosthesis using external implant, (C) Lowered occlusion was occurred in left molar restoration.
임플란트-지대주의 안정성은 지대주의 쐐기효과에 의해 지대주의 유지력이 증가하는데 기인한다. 임상에서는 나 사를 제거한 후에도 ICC 지대주의 유지력으로 인해 제거 할 때 상당한 어려움을 겪게 된다. 이런 현상은 일체형 지 대주일 때 더 큰 문제가 되므로 최근에 사용하는 대부분 의 지대주는 실린더와 나사로 구성되어 있다. Ricciardi Coppedê 등 ${ }^{20}$ 은 ICC에서 지대주 실린더의 유지력은 증 가하지만 나사는 반복적 수직하중을 가한 후 현저히 감 소된 풀림회전력을 나타낸다고 보고하였다. 하지만 ICC 와 EXT가 풀림회전력 차이를 보이지 않은 보고도 있 다. ${ }^{21}$ 이는 반복하중 유무나 하중의 방향성 차이 때문으 로 보인다. 임상에서도 장기간 사용한 ICC에서 나사의 전하중이 완전히 소실되어 있는 현상을 관찰할 수 있다. 이런 현상이 발생하는 이유는 정상적 저작기능으로 인한 수직변위로 인해 나사의 인장력이 감소하여 전하중 감소 를 초래하기 때문이라 추정되지만 다른 혼동요인들을 확 실히 제거한 후 진행하는 실험이 필요하다. $30 \mathrm{Ncm}$ 의 토 크를 가한 후 $20-250 \mathrm{~N}$ 의 반복하중을 $14 \mathrm{~Hz}$ 로 10 만회 시행하면서 2 만회마다 나사의 추가적인 재조임의 효과 를 비교한 연구를 했을 때, EXT는 재조임을 했을 때와 하지 않았을 때 풀림회전력의 차이가 없었으나 ICC에서 는 재조임을 가했을 때에 비해 재조임을 하지 않았을 때 풀림회전력이 유의하게 감소하는 결과를 보여, ICC는 주 기적인 나사재조임으로 낮아진 풀림회전력을 극복해야 함을 알 수 있다(Fig. 3). ${ }^{17}$

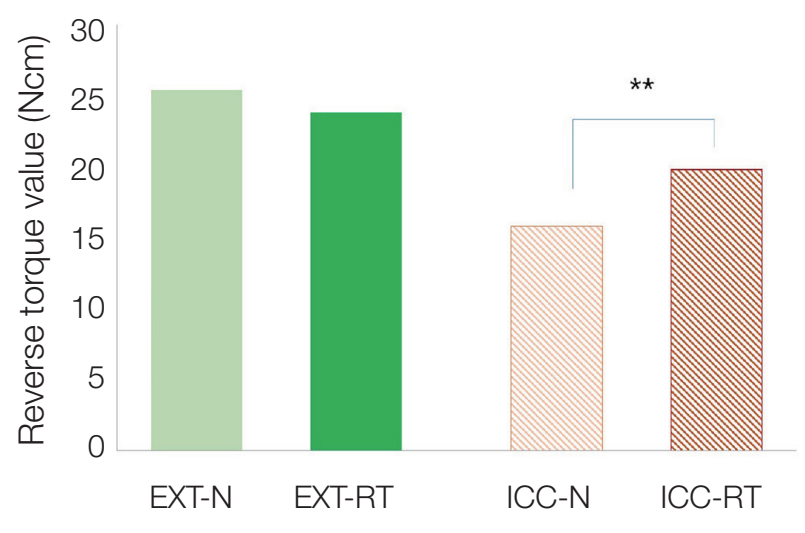

Fig. 3. Reverse torque value was lower in internal conical connection (ICC) comparing with external implant (EXT). In EXT, retightening (RT) did not affect the reverse torque value, while retightening of screws was effective in ICC implant. 
ICC의 임플란트-지대주 접촉이 크다는 것은 달리 해석 하면 접촉계면에 응력이 집중된다는 것이다. Pessoa 등 ${ }^{22}$ 은 유한요소 분석을 통해 ICC의 지대주 하방과 임플란 트 상부에 응력이 집중한다고 하였으며, Cho 등 ${ }^{23}$ 은 완 벽한 결합의 임플란트-보철물을 가정하더라도 ICC 특 유의 쐐기효과 영향으로 임플란트-지대주 간 접촉면에 높은 응력을 나타낸다고 하였다. 이러한 응력은 부적합 이 있을 때는 더욱 증가할 가능성이 있으며 단일 임플란 트 수복물보다는 다수 임플란트를 연결하는 수복물에서 더 크다. Jimbo 등 $^{24}$ 은 ICC에서 2 개의 연결된 나사 유지 형 보철물을 컴퓨터를 통해 예측해 보았을 때 $50 \mu \mathrm{m}$ 이 넘는 수직적 오차가 있으며 이런 오차는 티타늄 임플란 트의 항복강도를 넘어서는 응력집중을 야기할 수 있다고 하였다. 연결부의 응력집중은 구성요소의 파절빈도에도 반영된다(Fig. 4). Yi 등 ${ }^{25}$ 에 의하면 EXT의 전체 파절비 율이 $2 \%$ 정도인데 반해 ICC 구성요소의 파절은 5 배 이 상 높은데, 대부분이 지대주의 파절이며 임플란트 본체 의 파절도 ICC에서 더 높게 나타나지만 나사의 파절빈도 는 EXT와 ICC의 차이가 나지 않는다고 하였다.

갈수록 널리 적용되고 있는 ICC를 현명하게 적용하려 면 주변골 유지, 연조직 두께 확보, 안정적인 임플란트-지 대주 연결 및 임플란트 수술의 편의성 등의 장점을 잘 활 용하면서 생역학적인 특성 즉 수직변위와 지대주/임플 란트 연결부의 응력집중을 이해하고 불리한 상황을 피할 수 있는 수술과 식립방법을 사용해야 할 것이다.

\section{원추형 내부연결 임플란트의 식립 및 보철 시 고려할 사항}

\section{식립 시 고려사항}

무엇보다 ICC 임플란트를 식립한 후 겪는 최대의 문제 는 임플란트 본체 파절이다(Fig. 5). 2000년대 들어 파절 된 ICC 임플란트를 제거하는 보고들을 요약해 보면 특 히 좁은 직경 $(\mathrm{NP})$ 이나 일반 직경 $(\mathrm{RP})$ 의 임플란트들이 환 자의 저작력이 최대한으로 가해지는 구치부에서 파절된 다. ${ }^{25,26} \mathrm{Cha}$ 등 ${ }^{26}$ 은 임플란트 상부파절은 대부분 일반 직 경(RP)에서 발생하며 대부분 나사풀림을 몇 번 동반하다 가 파절된다고 하였다.

환자의 저작력을 완전히 조절할 수는 없기 때문에 치 과의사는 처음 식립할 때 임플란트 선택에 주의해야 한 다. 본 연구팀에서는 다양한 연구를 통해 ICC임플란트 상부 벽두께의 중요성을 강조해 왔다. 유한요소분석에 서 좁은 직경(NP)의 ICC에서는 특히 임플란트 최상부에 큰 응력이 집중되었다. ${ }^{23}$ 하지만 RP직경의 임플란트라고 해도 안전한 것은 아니다. ${ }^{27}$ 같은 RP직경의 임플란트라 도 실제 상부 벽두께는 다르기 때문이다(Fig. 6). 내경이 동일하고 외벽이 평평한 임플란트의 상부 벽두께만 다르 도록 제작하여 반복하중을 가하였을 때의 수직변위와 임 플란트의 실제 확장결과를 Fig. 7에 제시하였다. 임플란 트의 상부 확장은 $6-15 \mu \mathrm{m}$ 정도이며 수직변위는 30 -
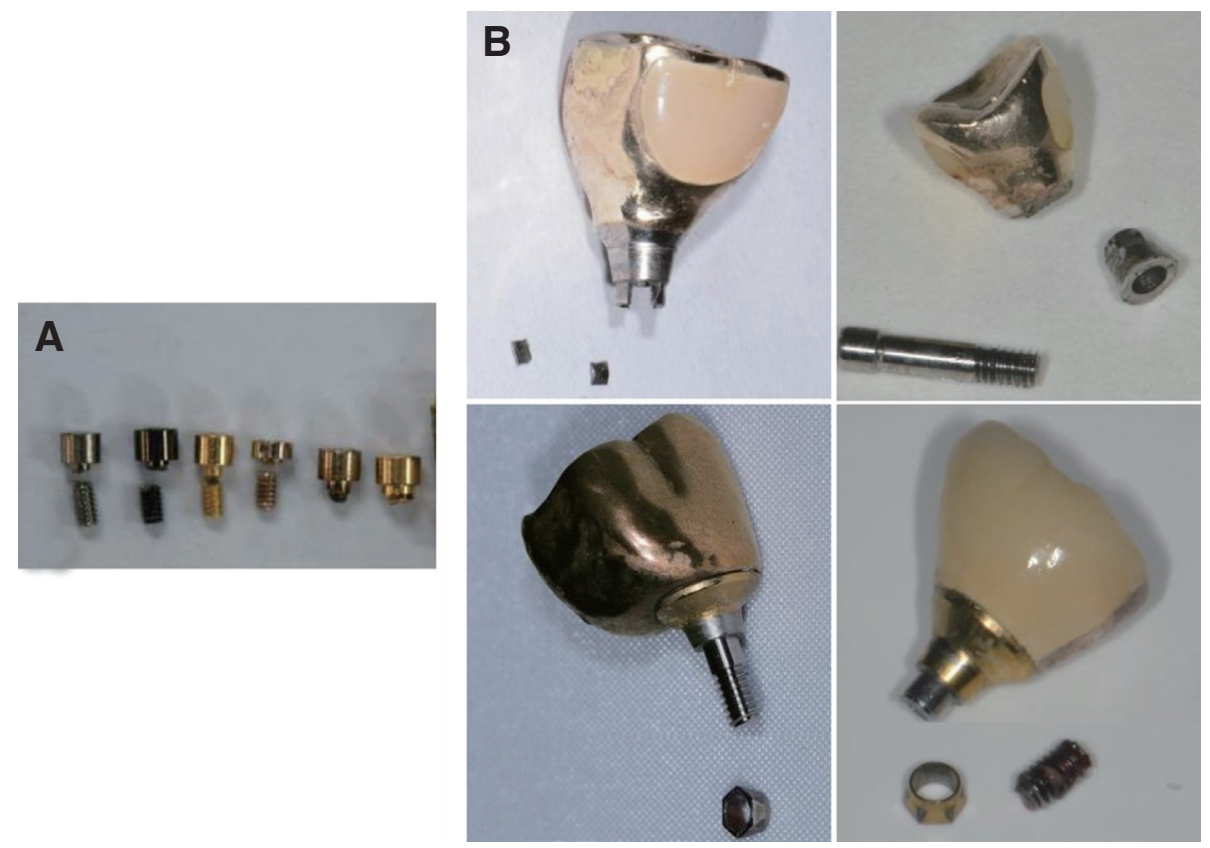

Fig. 4. (A) Various screw fractures, (B) Various abutment fractures occurred in ICC implant. 


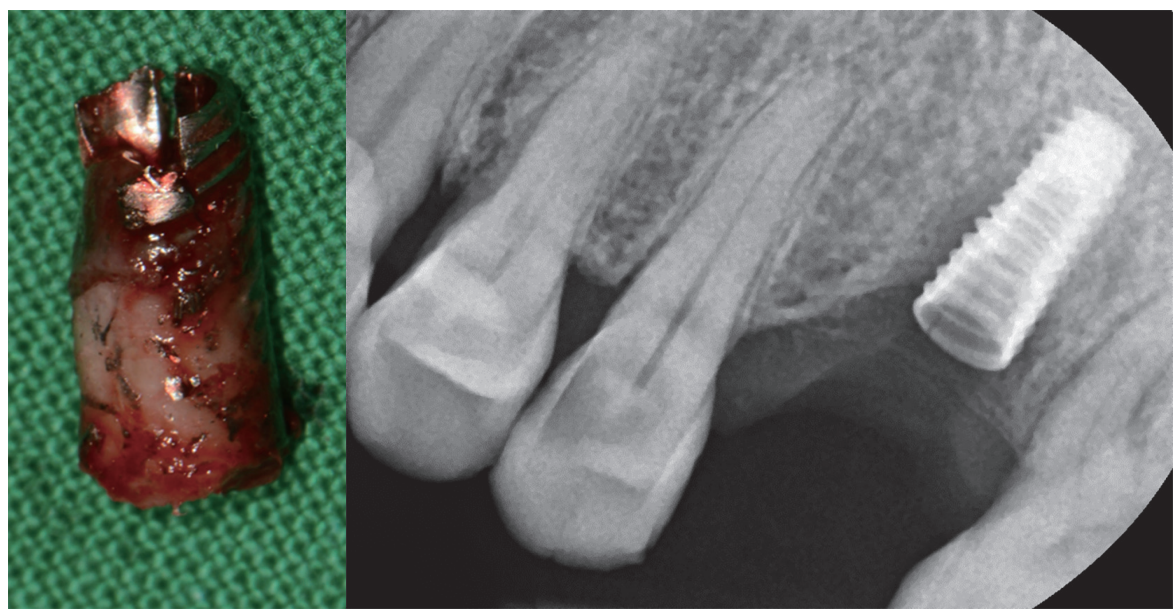

Fig. 5. Implant fracture was happened after repetitive retightening of screw in ICC. Crack in implant coronal wall can be found in retrieved implant and radiographic image.
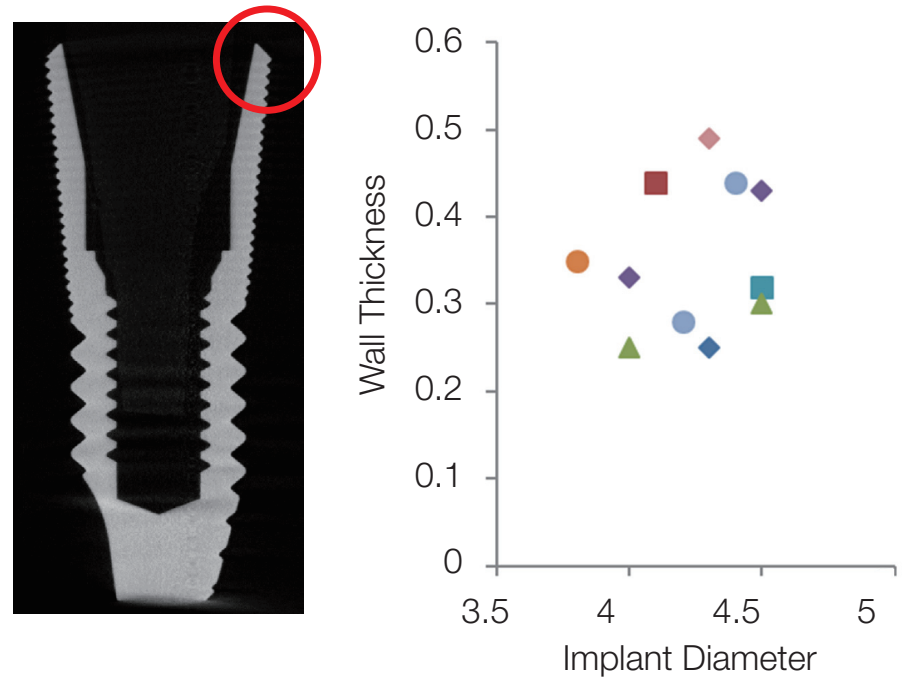

- NobelActive (NobelBiocare)

- NobelReplaceConicalConnection (NobelBiocare)

Bone Level Implant (Straumann)

OsseoSpeed TX (AstraTech)

$\triangle$ IS-II (Neo Biotech)

- Luna (Shinhung)

- Implantium (Dentium)

- TS III (Osstem)

Fig. 6. Distribution of coronal wall thickness of commercially available ICC regular platform implant systems. The thinnest wall thicknesses ranged from 0.2 to $0.5 \mathrm{~mm}$.

$50 \mu \mathrm{m}$ 정도로 나타났는데 특히 임플란트의 상부 벽두께 에 따라 이런 수치들은 차이가 났다. 가장 얇은 임플란트 에서는 토크를 가할 때 임플란트 상부의 확장이 가장 크 게 발생하고 이로 인해 지대주는 가장 큰 수직변위를 보 이며 이에 따라 나사의 풀림토크가 제일 많이 감소하였 다. 이러한 실험을 넓은 직경(WP)의 임플란트에 적용하 면 $4.5 \mathrm{~mm}$ 직경의 RP 임플란트나 $4.0 \mathrm{~mm}$ 직경의 RP 임 플란트에 비해서도 더 작은 수직변위와 풀림토크 감소를 보였다. ${ }^{28}$ 따라서 구치부에서는 RP보다는 WP를 사용하 고 RP를 소구치에 사용할 때도 가급적 직경이 더 큰 임 플란트를 선택하는 것이 좋다.
$\mathrm{ICC}$ 는 임플란트 본체보다 작은 직경을 가지는 지대주 를 연결하여 플랫폼 스위칭 효과를 얻기 때문에 주변골 의 상태나 연조직의 깊이에 상관 없이 지대주를 연결하기 가 용이하다. 따라서 골형태만 허용한다면 피판을 거상 하지 않는 수술에 최적화된 시스템이다.

ICC 식립 시 우선적으로 고려해야 하는 사항은 식립 깊이이다. Weng 등 ${ }^{6,7}$ 은 ICC가 치조골보다 상부에 식립 되었을 때는 수직적 골소실을 유발하지만 치조골보다 하 부에 식립되면 골생성을 유도한다고 하였다. 건강한 치 조정 상방의 조직부착(이전에 biologic width라고 알려졌 으나 현재는 supracrestal tissue attachment라고 쓰는 것 

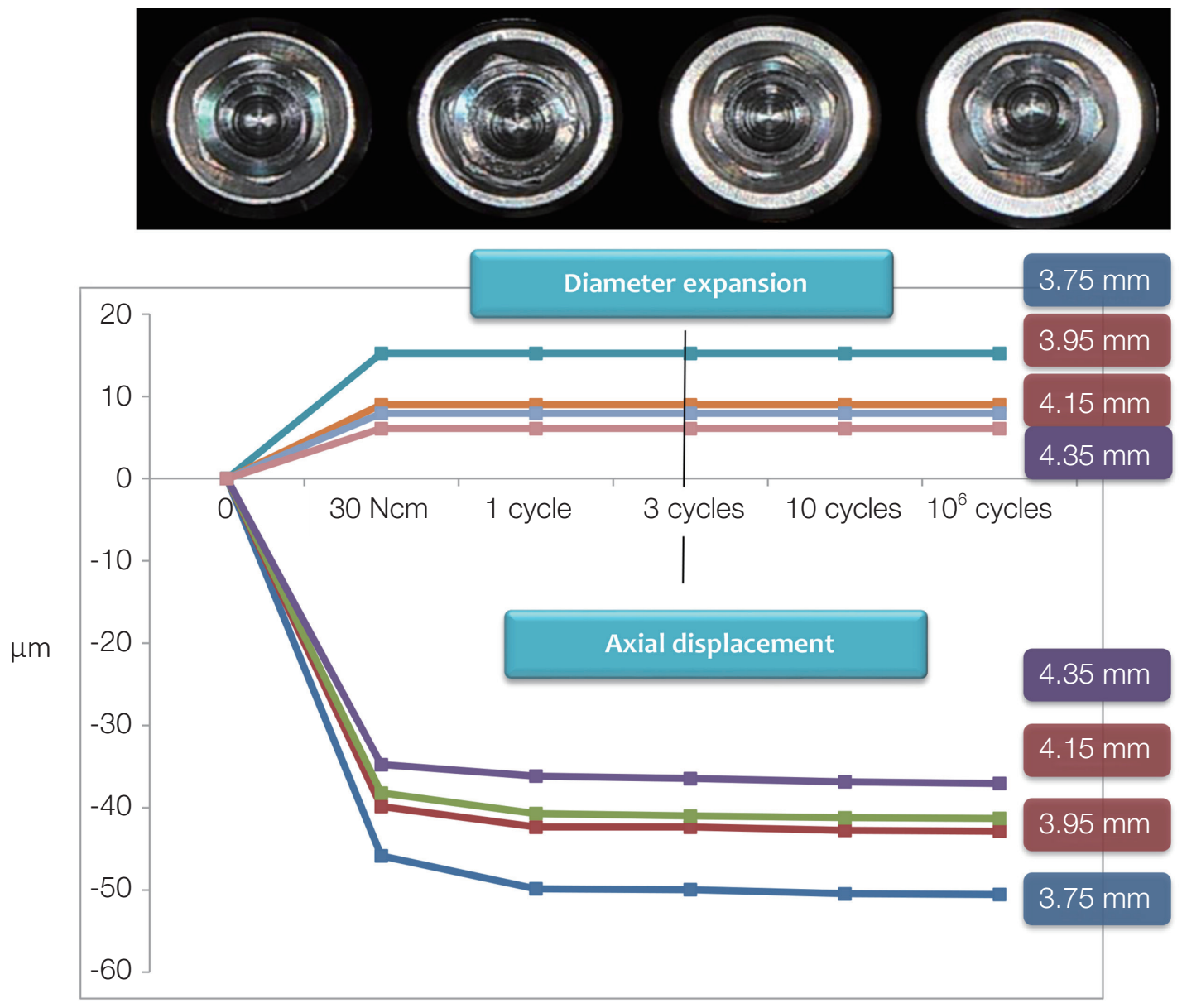

Fig. 7. Diameter expansion ( $\mu \mathrm{m}$; positive line graphs) and axial displacement ( $\mu \mathrm{m}$; negative line graphs) of experimental implant-abutment assembly after screw tightening and cyclic loadings. Experimental implants with coronal wall thickness (0.2 mm, $3.75 \mathrm{~mm}$ diameter; $0.3 \mathrm{~mm}, 3.95 \mathrm{~mm} ; 0.4 \mathrm{~mm}, 4.15 \mathrm{~mm} ; 0.5 \mathrm{~mm}, 4.35 \mathrm{~mm}$ ). The diameter expansion was significantly small in the $4.35 \mathrm{~mm}$ implant larger $(P<0.001)$. The axial displacement of the $3.75 \mathrm{~mm}$ and $3.95 \mathrm{~mm}$ groups was significantly larger $(P<0.001)$.

이 권장됨) 깊이는 자연치에서는 약 $3 \mathrm{~mm}$, 임플란트 주 변에서는 약 $4.4 \mathrm{~mm}$ 이다. ${ }^{29}$ 조직부착은 항상성을 가지려 는 경향이 있는데 Lindhe와 Berglundh ${ }^{30}$ 는 치조정에 맞 추어 연조직 깊이가 $2 \mathrm{~mm}$ 가 되도록 식립한 경우 주변골 이 흡수되면서 연조직 깊이가 $4 \mathrm{~mm}$ 가 되지만 처음부터 연조직 깊이가 $4 \mathrm{~mm}$ 가 되도록 식립한 경우에는 주변골 흡수가 진행되지 않는다고 하였다. 식립깊이는 골유착이 이루어지는 동안만이 아니라 유지의 측면에서도 중요한 데 생역학적으로 치조골보다 상부에 위치한 ICC에서는 임플란트 상부에 5 배 이상의 응력이 집중된다고 한다. ${ }^{31}$ 따라서 $4 \mathrm{~mm}$ 의 연조직 깊이를 확보할 수 있도록 식립하 는 것이 중요하다.

특별한 조건에서는 추가적인 고려사항이 필요하다. Monje 등 ${ }^{32}$ 은 임플란트 주위염을 유발하는 다양한 요인
중 임플란트가 협측으로 식립된 것이 $40.5 \%$ 라고 하면서 연조직 관련 요인도 $50 \%$ 의 기여요인이 된다고 하였다. 연조직 요인 중 각화점막의 양이 작은 경우가 $29 \%$, 조직 형(biotype)이 얇은 경우가 $21 \%$ 정도 되므로 이런 연조 직 조건을 가지고 있다면 조금 더 깊이 식립하는 것이 추 가적인 문제를 방지하는 방안이 될 것이다.

\section{보철 시 고려사항}

ICC 임플란트는 식립이 쉬운 반면 보철 시 고려해 야 할 사항이 많다. 특히, 요즘 대세가 되고 있는 CAD$\mathrm{CAM}$ 보철물을 제작할 때 주의할 사항이 많다. $\mathrm{CAD}$ $\mathrm{CAM}$ 지대주 사용 시 제작과정을 이해하고 적절한 환봉 을 선택해야 하며, 기성 지대주에 비해 적합이 불량할 가 
능성이 있으므로 제작과정이나 연결과정을 세심하게 확 인해야 한다. 임플란트와 지대주의 각 연결부나 나사가 공의 정밀성을 고려해야 한다. ${ }^{33}$ 설계면에서는 임상상 황에 맞추어 지대주 연결구조를 선택하고 보철물 유형 에 따라 지대주의 높이, 각도, 형태 및 변연의 높이를 설 정해야 한다. 출현윤곽과 치은접촉 형태는 특히 중요한 데, ${ }^{34}$ 얕게 식립된 임플란트에 지대주가 넓게 퍼지는 경우 골흡수와 음식물 저류를 유발하는 가장 불리한 선택이 므로 식립 위치에 따라 지대주의 폭경을 조절해야 한다. Blanco 등 ${ }^{35}$ 은 지대주의 길이가 긴 것만으로도 임플란트 주변골 흡수를 감소시킬 수 있다고 하였다.

간단한 임플란트 보철물 제작에서도 여러 번의 연결과 정을 거친다. 이러한 연결과정에서 통제되지 않은 수작 업의 조임력으로 각각의 단계를 진행한다면 제작된 보철 물은 각 단계의 수직 변위로 인해 큰 오차를 가질 수 밖 에 없다. 더 큰 문제는 임플란트와 지대주의 오체결에 의 한 연결부 불안정성이다. 오체결(misconnection)이 있으 면 봉쇄(perfect seal)가 이루어지지 않아 생물학적인 세 균오염과 함께 생역학적인 문제를 심화시킬 수 있다. 특 히 ICC에서는 장기적인 문제가 발생한 후에 그 원인을 오체결이라 추정하는 경우가 많다(Fig. 2). 이는 ICC에서 오체결을 확인하기가 어렵기 때문이다. 가급적 임플란트 에 지대주를 개별적으로 연결한 후 방사선사진으로 임플 란트-지대주의 원추형 접촉부와 나사 하방공간의 크기를
비교하여 정체결을 확인한 후 토크를 가하는 것이 좋다.

오체결을 유발하는 요인 중 하나는 호환성 지대주를 사용하는 것이다. 임플란트의 원추형태는 제조사에 따 라 다른 각도 및 접촉면을 가진다. 호환성 지대주를 사용 할 경우 각도와 접촉면 불일치로 인한 생역학적 문제를 유발할 수 있다. ${ }^{33}$ 정확히 맞지 않는 지대주를 연결할 경 우 미세동요가 발생하며 이는 표면변화를 유발하여 탄성 변형과 미세간극을 증가시킨다. ${ }^{36,37}$ 호환성 지대주는 임 플란트 내부와 정확히 일치하는 경사가 아닌 경우 초기 에 큰 양의 수직변위가 발생할 수도 있고 기능 후 장기적 으로 수직변위가 발생할 수도 있다. 또한 호환성 지대주 는 제품의 공차가 다르며 표면조도 조절이나 밀링 후 처 리가 부실할 가능성을 배제할 수 없고 특히 짧은 길이의 임플란트를 식립한 경우 나사가 임플란트 내부 바닥에 닿는 문제가 발생할 수도 있으므로 가급적 사용하지 않 아야 한다. 같은 내부경사를 가진 임플란트라도 임플란 트와 지대주의 체결특성(engagement feature)에 따라 다 른 응력이 나타난다(Fig. 8). ${ }^{38}$ 임플란트의 상부와 하방에 서 접촉하는 이중체결형에서 하방의 체결부위에 큰 응 력이 집중되어 지대주파절이 더 많이 발생하는 원인이 라고 추정된다. 따라서 가급적 지대주 중에서는 육각형 (hexagnoal) 지대주를 사용하며 이중체결형이라면 가급 적 원추형(conical, non-hex)를 사용하는 것이 응력분산 에 더 유리하다.
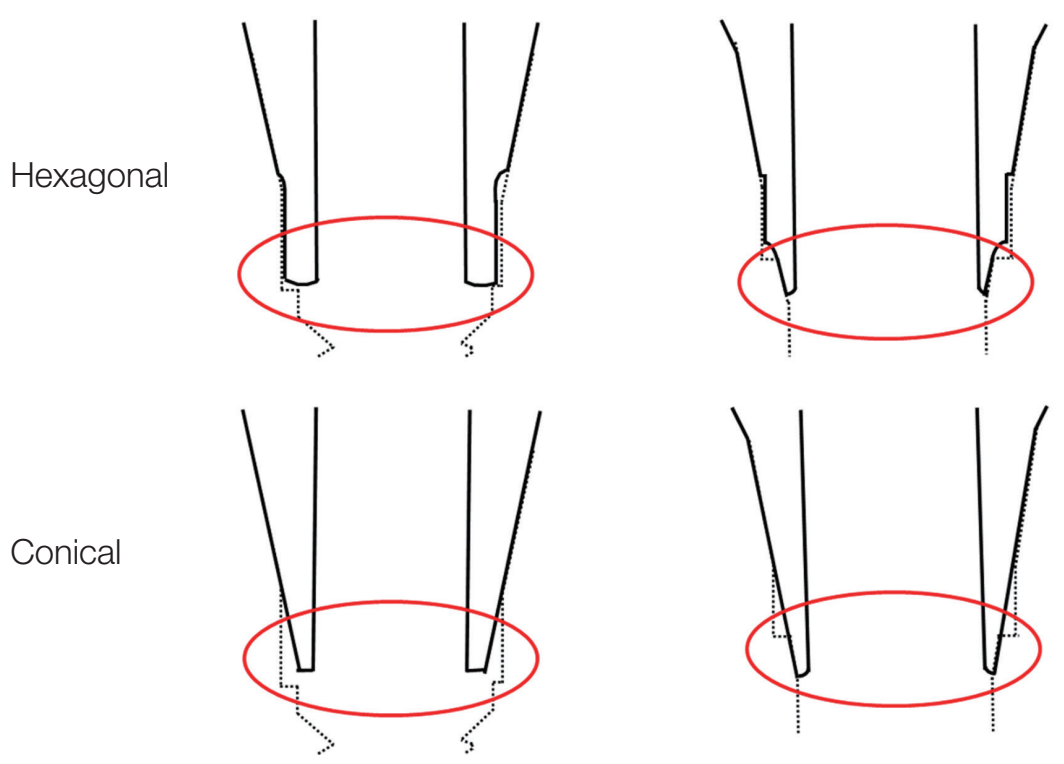

Fig. 8. Single engagement feature (left) and double engagement feature (right). 

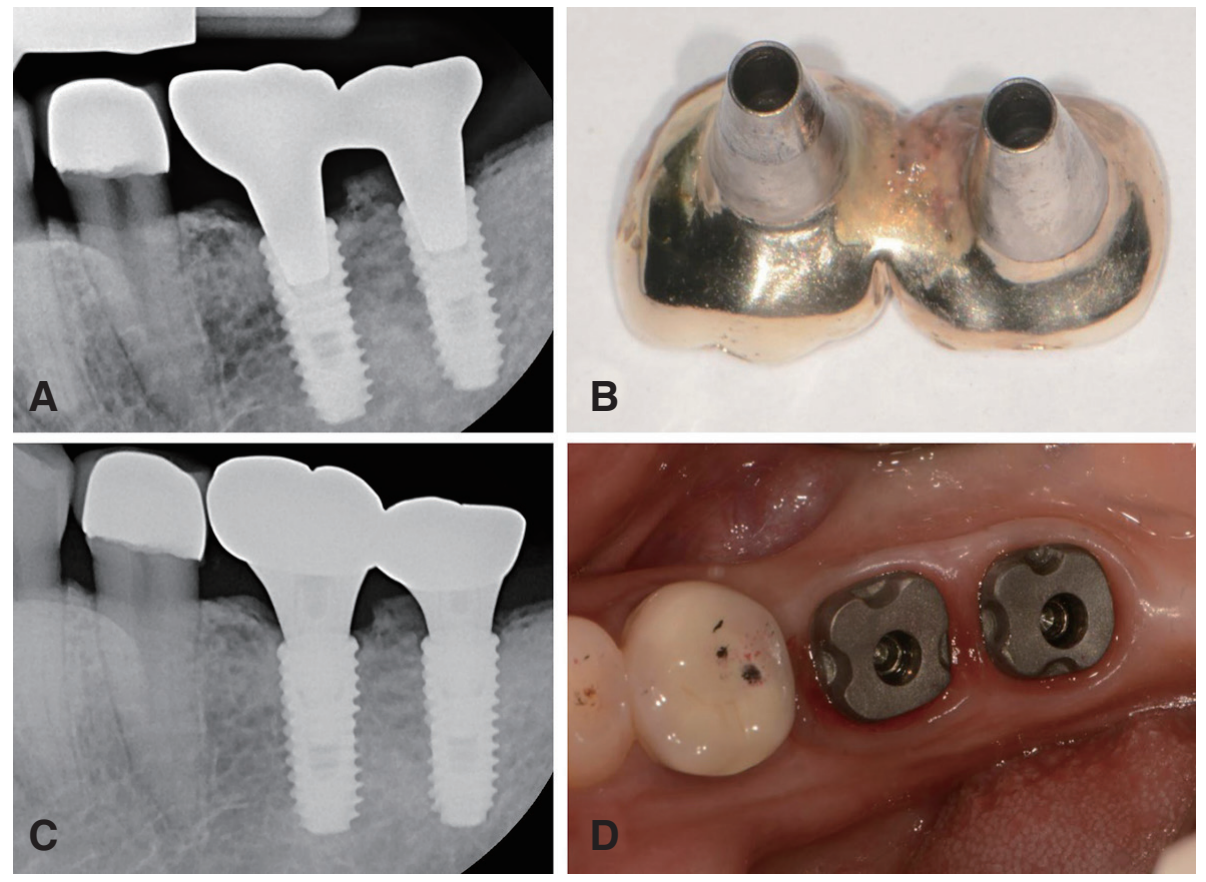

Fig. 9. (A, B) Screw retained prosthesis splinting 2 ICC implants. Screw loosening and plaque accumulation under prosthesis. (C, D) Screw and cement retained prosthesis (SCRP) using CAD-CAM abutments (Courtesy of Dr. Park JH).

회전방지 구조인 육각형태는 지대주를 반복적으로 같 은 위치에 연결할 수 있게 해주므로 시멘트유지형에서 선 호되는 연결부이다. 원추형 연결부는 임플란트와 지대주 의 접촉면적을 $50 \%$ 정도 더 증가시켜 연결부 안정성이 우수하고 수직변위 방지에도 효과적이다. 무엇보다 원추 형 연결구조를 사용할 경우 오체결의 가능성을 줄일 수 있고 착탈용이성 확보에도 유리하다. 원추형 구조는 나 사유지형이나 시멘트-나사유지형(screw and cement retained prosthesis, SCRP) 보철물에 사용하며 회전방지가 필요 없는 다수 임플란트 연결 보철에서 사용하는 방식이 다. 단일 임플란트일 때는 어쩔 수 없더라도 다수 임플란 트에서는 가급적 원추형 지대주를 선택하는 것이 좋다.

보철물 유지 방식 중 다수 임플란트를 본체에서 연결 하는 나사유지형은 적합도와 오체결의 측면에서 가장 불 리한 형태이다(Fig. 9). 제작이 쉬우며 오체결의 가능성이 낮은 시멘트유지형 보철물은 나사유지형에 비해 수직변 위에 더 취약하며 유지관리도 어렵다. 따라서 지대주를 따로 체결하고 보철물을 연결하는 SCRP가 ICC에 가장 적합한 방식이라고 할 수 있다. 보철물의 재료에 따라서 도 수직변위량이 다른데 탄성계수가 높은 보철재료(지르 코니아나 $\mathrm{Co}-\mathrm{Cr}$ )보다 탄성계수가 낮은 보철재료에서 수
직변위가 더 크게 나타남을 감안한다면 구치부의 ICC에 서는 임시수복물을 일정 기간 이상 적용하여 일정 수준의 수직변위를 유발한 후 최종보철을 진행하는 것이 교합이 낮아지는 현상을 방지할 수 있는 가장 좋은 방법이다.

\section{결론}

ICC는 생물학적 우수성과 측방력에 저항하는 임플란 트-지대주 접촉을 가지고 있으나 수직변위에 의한 생역 학적 취약점을 가진다. ICC를 잘 활용하기 위해서는 상 부 벽두께를 최대화 할 수 있는 큰 직경의 임플란트를 선 택하여 치조정보다 낮게 식립해야 한다. 특히 연조직 조 건이나 골조건이 불리할 때는 더 깊게 식립하는 것이 유 리하다. 연조직 깊이에 따라 지대주 넓이를 결정하는 것 이 필요하며, 식립깊이가 얕으면 직경을 줄여야 한다. 오 체결을 최소화하기 위해 호환성 지대주보다는 기성 지대 주나 정품 티타늄 환봉을 선택하고, 다수의 임플란트를 연결하는 경우에는 원추형 연결방식의 SCRP로 수복하 는 것이 유리하며 대구치에서는 임시보철물을 활용하는 것이 장기적으로 안정된 임상결과를 얻을 수 있는 방법 이 될 것이다. 


\section{ORCID}

Kyung-Ho Ko https://orcid.org/0000-0002-1260-8844

Hyeon-Goo Kang https://orcid.org/0000-0001-6293-0121

Yoon-Hyuk Huh https://orcid.org/0000-0003-4072-5199

Chan-Jin Park https://orcid.org/0000-0003-4734-214X

Lee-Ra Cho https://orcid.org/0000-0003-3989-2870

\section{References}

1. Bonfante EA, Coelho PG. A critical perspective on mechanical testing of implants and prostheses. Adv Dent Res 2016;28:18-27.

2. Sutter F, Weingart D, Mundwiler U, Sutter FJ, Asikainen P. ITI implants in combination with bone grafts: design and biomechanical aspects. Clin Oral Implants Res 1994;5:164-72.

3. Norton MR. An in vitro evaluation of the strength of an internal conical interface compared to a butt joint interface in implant design. Clin Oral Implants Res 1997;8:290-8.

4. Levine RA, Clem DS 3rd, Wilson TG Jr., Higginbottom F, Solnit G. Multicenter retrospective analysis of the ITI implant system used for single-tooth replacements: results of loading for 2 or more years. Int J Oral Maxillofac Implants 1999;14:51620.

5. Baggi L, Cappelloni I, Di Girolamo M, Maceri F, Vairo G. The influence of implant diameter and length on stress distribution of osseointegrated implants related to crestal bone geometry: a threedimensional finite element analysis. J Prosthet Dent 2008;100:422-31.

6. Weng D, Nagata MJ, Bell M, Bosco AF, de Melo LGN, Richter E. Influence of microgap location and configuration on the periimplant bone morphology in submerged implants. An experimental study in dogs. Clin Oral Implants Res 2008;19:11417.

7. Weng D, Nagata MJH, Bell M, de Melo LGN, Bosco AF. Influence of microgap location and configuration on peri-implant bone morphology in nonsubmerged implants: an experimental study in dogs. Int J Oral Maxillofac Implants 2010;25:540-7.
8. Lee JH, Kim DG, Park CJ, Cho LR. Axial displacements in external and internal implant-abutment connection. Clin Oral Implants Res 2014;25:e83-9.

9. Seol HW, Heo SJ, Koak JY, Kim SK, Kim SK. Axial displacement of external and internal implantabutment connection evaluated by linear mixed model analysis. Int J Oral Maxillofac Implants 2015;30:1387-99.

10. Braian M, De Bruyn H, Fransson H, Christersson $\mathrm{C}$, Wennerberg A. Tolerance measurements on internal- and external-hexagon implants. Int J Oral Maxillofac Implants 2014;29:846-52.

11. Winkler S, Ring K, Ring JD, Boberick KG. Implant screw mechanics and the settling effect: overview. J Oral Implantol 2003;29:242-5.

12. Bulaqi HA, Mashhadi MM, Safari H, Samandari MM, Geramipanah F. Dynamic nature of abutment screw retightening: finite element study of the effect of retightening on the settling effect. J Prosthet Dent 2015;113:412-9.

13. Merz BR, Hunenbart S, Belser UC. Mechanics of the implant-abutment connection: an 8-degree taper compared to a butt joint connection. Int J Oral Maxillofac Implants 2000;15:519-26.

14. Bozkaya D, Müftü S. Mechanics of the tapered interference fit in dental implants. J Biomech 2003;36:1649-58.

15. Baixe S, Fauxpoint G, Arntz Y, Etienne O. Microgap between zirconia abutments and titanium implants. Int J Oral Maxillofac Implants 2010;25:45560.

16. Teoh SH, Thampuran R, Seah KHW, Goh JCH. The development of $\mathrm{P} / \mathrm{M}$ titanium-graphite triphasic composites for biomedical applications. J Mater Sci Ltr 1997;16:639-41.

17. Cho WR, Huh YH, Park CJ, Cho LR. Effect of cyclic loading and retightening on reverse torque value in external and internal implants. J Adv Prosthodont 2015;7:288-93.

18. Jeon BS, Kim SK, Lee JJ, Seo JM. Possibility and limitation of applying occlusal adjustment on implant prosthesis similar to natural teeth. Implantology 2018;22:162-72.

19. Theoharidou A, Petridis HP, Tzannas K, Garefis P. Abutment screw loosening in single-implant resto- 
rations: a systematic review. Int J Oral Maxillofac Implants 2008;23:681-90.

20. Coppedê AR, de Mattos MG, Rodrigues RCS, Ribeiro RF. Effect of repeated torque/mechanical loading cycles on two different abutment types in implants with internal tapered connections: an in vitro study. Clin Oral Implants Res 2009;20:624-32.

21. Piermatti J, Yousef H, Luke A, Mahevich R, Weiner S. An in vitro analysis of implant screw torque loss with external hex and internal connection implant systems. Implant Dent 2006;15:427-35.

22. Pessoa RS, Muraru L, Júnior EM, Vaz LG, Sloten JV, Duyck J, Jaecques SVN. Influence of implant connection type on the biomechanical environment of immediately placed implants - CT-based nonlinear, three-dimensional finite element analysis. Clin Implant Dent Relat Res 2010;12:219-34.

23. Cho SY, Huh YH, Park CJ, Cho LR. ThreeDimensional Finite Element Analysis of the Stress Distribution at the Internal Implant-Abutment Connection. Int J Periodontics Restorative Dent 2016;36:e49-58.

24. Jimbo R, Halldin A, Janda M, Wennerberg A, Vandeweghe S. Vertical fracture and marginal bone loss of internal-connection implants: a finite element analysis. Int J Oral Maxillofac Implants 2013;28:e171-6.

25. Yi Y, Koak JY, Kim SK, Lee SJ, Heo SJ. Comparison of implant component fractures in external and internal type: A 12-year retrospective study. J Adv Prosthodont 2018;10:155-62.

26. Cha HS, Kim YS, Jeon JH, Lee JH. Cumulative survival rate and complication rates of single-tooth implant; focused on the coronal fracture of fixture in the internal connection implant. J Oral Rehabil 2013;40:595-602.

27. Lee JH, Huh YH, Park CJ, Cho LR. Effect of the Coronal Wall Thickness of Dental Implants on the Screw Joint Stability in the Internal Implant-Abutment Connection. Int J Oral Maxillofac Implants 2016;31:1058-65.

28. Lee JH, Lee W, Huh YH, Park CJ, Cho LR. Impact of Intentional Overload on Joint Stability of Internal Implant-Abutment Connection System with Different Diameter. J Prosthodont 2019;28:e649-
56.

29. Parpaiola A, Cecchinato D, Toia M, Bressan E, Speroni S, Lindhe J. Dimensions of the healthy gingiva and peri-implant mucosa. Clin Oral Implants Res 2015;26:657-62.

30. Lindhe J, Berglundh T. The interface between the mucosa and the implant. Periodontol 2000 1998;17:47-54.

31. Hansson S. The implant neck: smooth or provided with retention elements. A biomechanical approach. Clin Oral Implants Res 1999;10:394-405.

32. Monje A, Galindo-Moreno P, Tözüm TF, SuárezLópez del Amo F, Wang H. Into the Paradigm of Local Factors as Contributors for Peri-implant Disease: Short Communication. Int J Oral Maxillofac Implants 2016;31:288-92.

33. Ko KH, Park JH, Cho LR. Considerations for fabrication of cad-cam abutments: Part I. Selection of titanium block and fabrication process. Implantology 2019;23:46-58.

34. Ko KH, Park JH, Cho LR. Considerations for fabrication of cad-cam abutments: Part II. Designing abutment. Implantology 2019;23:112-25.

35. Blanco J, Pico A, Caneiro L, Nóvoa L, Batalla P, Martín-Lancharro P. Effect of abutment height on interproximal implant bone level in the early healing: A randomized clinical trial. Clin Oral Implants Res 2018;29:108-17.

36. Zabler S, Rack T, Rack A, Nelson K. Fatigue induced deformation of taper connection in dental titanium implants. Int J Mat Res 2012;103:207-16.

37. Rack T, Zabler S, Rack A, Riesemeier H, Nelson K. An in vitro pilot study of abutment stability during loading in new and fatigue-loaded conical dental implants using synchrotron-based radiography. Int J Oral Maxillofac Implants 2013;28:44-50.

38. Cho SY, Huh YH, Park CJ, Cho LR. Three-dimensional finite element analysis on stress distribution of internal implant-abutment engagement features. Int J Oral Maxillofac Implants 2018;33:319-27. 


\section{임플란트 연결부의 개념과 적용: Part 1. 원추형 내부연결 임플란트의 식립과 보철}

고경호 조교수, 강현구 전임의, 허윤혁 부교수, 박찬진 교수, 조리라* 교수

강릉원주대학교 치과대학 보철학교실 및 구강과학연구소

원추형 내부연결 임플란트의 독특한 생역학적 현상이 수직침하와 전하중 상실이다. 원추형 내부연결 임플란트에서 수직 적 정지점의 부재로 발생하는 수직침하에 의해 나사의 전하중이 상실되고 교합이 낮아지는 현상이 유발된다. 원추형 내 부연결 임플란트에 발생하는 응력은 나사가 아니라 지대주가 접촉하는 계면에 집중되므로 식립할 때는 가급적 상부직경 이 두꺼운 임플란트를 선택하는 것이 중요하다. 원추형 내부연결 임플란트는 치조정보다 하방에 식립해야 하며 수복 시 에는 적절한 지대주 형태와 정확한 연결을 가지는지 주의해야 한다. 최상의 임상적 결과를 얻기 위해서는 상부 직경을 잘 선택하고 적절한 위치에 식립하여 수복하는 것이 필요하다.

(구강회복응용과학지 2020;36(4):211-21)

주요어: 원추형 내부 연결방식; 수직침하; 전하중; 보철; 식립

*교신저자: 조리라

(25457)강원도 강릉시 죽헌길 7, 강릉원주대학교 치과대학 치과보철학교실 및 구강과학연구소

Tel: 033-640-3153 | Fax: 033-640-3103 | E-mail: lila@gwnu.ac. kr

접수일: 2020년 9월 17일 | 수정일: 2020년 10월 12일 | 채택일: 2020년 11월 20일 